\title{
The Cinchona Program (1940-1945): science and imperialism in the exploitation of a medicinal plant
}

\author{
Nicolás Cuvi (*) \\ $\left(^{*}\right)$ Facultad Latinoamericana de Ciencias Sociales, FLACSO-Ecuador; Centre d'Història de la \\ Ciència, Universitat Autònoma de Barcelona. ncuvi@flacso.org.ec
}

Dynamis

[0211-9536] 2011; $31(1): 183-206$
Fecha de recepción: 25 de enero de 2010

Fecha de aceptación: 27 de julio de 2010

SUMARIO: 1.-Introduction. 2.-Cinchona and its alkaloids. 3.-The War and the need for raw materials. 4.- The quest for Cinchona in the Andes. 5.-Extraction and sale of Cinchona. 6.-Nurseries, plantations and alkaloids factories. 7.-The end of the Cinchona Program. 8.-Epilogue.

ABSTRACT: During World War II, the United States implemented programs to exploit hundreds of raw materials in Latin America, many of them botanical. This required the participation of the country's scientific community and marked the beginning of intervention in Latin American countries characterized by the active participation of the United States in negotiations (and not only by private firms supported by the United States). Many federal institutions and companies were created, others were adapted, and universities, research centers and pharmaceutical companies were contracted. The programs undertaken by this coalition of institutions served to build and consolidate the dependence of Latin American countries on United States technology, to focus their economies on the extraction and development of resources that the United States could not obtain at home (known as «complementary») and to impede the development of competition. Latin American republics had been historically dependant on raw material exports (minerals and plants). But during World War II their dependence on US loans, markets, science and technology reached record levels. One example of this can be appreciated through a careful examination of the Cinchona Program, implemented in the 1940 s by US agencies in Latin America. This program for the extraction of a single medicinal plant, apart from representing a new model of scientific imperialism (subsequently renamed "scientific cooperation») was the most intensive and extensive scientific exploration of a single medicinal plant in the history of mankind.

KEY WORDS: Cinchona, Andean countries, Latin America, botanical explorations, scientific imperialism.

PALABRAS CLAVE: Quina, países andinos, Latinoamérica, exploraciones botánicas, imperialismo científico. 


\section{Introduction}

The history of scientific expeditions, sent from the northern kingdoms, empires, states and metropolis to the tropical areas of the planet, has served to illustrate how these enterprises have been instrumental in initiating or strengthening the dominance of new territories in Asia, Africa and America. The literature on these expeditions is abundant, especially for the Spanish, French and British since the sixteenth century onwards, but analyses about United States' scientific expeditions during the mid-twentieth century are less frequent, and in cases such as the one studied here, they are inexistent. Examination of these cases is essential to obtaining new insights into the complex international relations with regard to science, and how those relations evolve in a particular time and region. The Cinchona Program, implemented by US agencies in Latin America in the 1940s, is a very good case for exploration of this issue.

This paper examines an enterprise aimed at obtaining a group of medicinal plants well known to the history of science and medicine: members of the genus Cinchona. This case illustrates another instance of exploration of the tropics, embedded in the tradition of dominating labor and tropical nature through travel and the accumulation of information in the form of herbarium specimens, field notes, maps, drawings, seeds and plants. The novelty of the Cinchona Program (and the reason it deserves scholarly attention) is the size in terms of people involved and the volume of raw materials and information obtained. In the extensive history of Cinchona, the chapter on the US Cinchona Program is missing, despite it being the most intensive and extensive scientific exploration ever made of Cinchona, and of any other medicinal plant, in the history of humankind.

The paper also identifies the emergence of a new model of international scientific enterprise, a model that was consolidated and commonly applied in subsequent decades. The model is characterized by pronounced dependence on loans and non refundable aid; scientists to explore, negotiate and ultimately lead the work; the involvement of federal agencies with the bilateral cooperation of southern counterparts; and close relations with universities, pharmaceutical companies and research centers. As the United States did not have the same agency that the Spanish had enjoyed in Latin America (the attributes of a formal empire), it had to negotiate certain aspects of the venture. A completely new approach had to be developed for encouraging and monopolizing botanical commodities production in 
Latin America. The effort was a great success: the United States acquired privileges and power never before seen in its negotiations with all Latin American countries.

In addition, in the field of public health, as illustrated by several authors, US intervention during and after World War II left a lasting footprint in the American nations. Public health was targeted for even more training and investment, but what the programs really pursued was securing of US investment opportunities abroad and, later, cooperation against communist expansion, all under the guise of Pan-Americanism ${ }^{1}$. A study of this cooperation in Brazil, for example, illustrates the different expectations of US and Brazilian governments: the former was interested in an immediate and clearly defined military objective, while the later was immersed in a «state and nation building» program ${ }^{2}$.

In the field of agronomy, US technicians promoted the idea of lands without people with the knowledge needed to develop them; countries populated by ignorant peasants, a scheme that should be changed and modeled to the successful US model of agriculture. If, in the centuries before World War II, Latin American countries looked to Europe for their development/ scientific models, the strategies introduced by the United States served to change perceptions: now all eyes were focused, almost exclusively, on the science produced north of the Río Grande.

The Cinchona Program also represents an important chapter in the history of the environment. It is the tip of the iceberg, just one of a complex group of missions carried out in Latin America during World War II to exploit minerals, livestock, forest plants (balsa, quebracho, rubber, etc), and to promote the production of these and hundreds of others in frontier areas. The new ideas for agriculture, based on mechanization, the intensive use of external inputs such as fertilizers and pesticides, and oriented to complementary products, had a strong impact on nature and the agricultural frontier in Latin American. Again, this is not to say that previous interventions did not have an impact on tropical environments, or that US interventions had not shaped nature in Latin America or other areas before. Previous booms in tobacco, sugar and other commodities

1. Guzmán, María del Pilar; Emilio Quevedo. La cooperación técnica norteamericana en salud pública en Colombia durante la Segunda Guerra Mundial. Biomédica. 1999; 19 (1): 5-17.

2. Vieira de Campos, André Luis. La expansión de la autoridad estatal y el Servicio Especial de Salud Pública en el Brasil, 1942-1960. Dynamis. 2005; 25: 227-256. 
were huge, but the scale of the Cinchona Program remains, nevertheless, without precedent: in the 18th century, when the Spanish Kingdom exercised a 38-year monopoly on Cinchona production, 350 thousand pounds of Cinchona were shipped to the Real Botica in Spain ${ }^{3}$. By way of contrast, through the Cinchona Program, in about seven years, the United States imported around 40 million pounds of dry bark; this figure does not include the bark processed in Latin American factories.

Far from entering a discussion or dialogue with works that analyze science and imperialism (a topic on which there is much literature) ${ }^{4}$, or US imperialism and its relation with science and technology before and after World War II $^{5}$, the purpose of this paper is to call attention to a moment in which relations between the United States and Latin America related to «science and imperialism» acquired a new face within the «cooperation for development» framework. It is not my intention to downplay the importance of other US interventions in commodities production in Latin America (a topic that has been studied in the case of bananas, rubber, sugarcane, agricultural stations overseas, etc. $)^{6}$, nor to underestimate the relevance that other US scientific endeavors (such as in medicine) have had in Latin America. The United States Department of Agriculture (USDA), the New York Botanical Garden, the Missouri Botanical Garden, the Field Museum of Natural History and other institutions had been sending «plant hunters» around the world to collect tropical plants since the early 20th century, resulting in massive collections. US scientists had been working around the world for many decades, but the number involved during the war, the support they received, and the kind of scientific cooperation established

3. De Andrés Turrión, María Luisa. Quina del Nuevo Mundo para la Corona española. Asclepio. 1989; 41 (1): 305-324.

4. For example: MacLeod, Roy. Introduction. Osiris. 2000; 15: 1-13; Palladino, Paolo; Worboys, Michael. Science and imperialism. Isis. 1993; 84 (1): 91-102.

5. Cueto, Marcos, ed. Missionaries of Science. The Rockefeller Foundation and Latin America. Bloomington and Indianapolis: Indiana University Press; 1994; McCook, Stuart. States of nature: science, agriculture and environment in the Spanish Caribbean, 1760-1940. Austin: University of Texas Press; 2000; Krige, John; Barth, Kai-Henrik. Introduction: science, technology, and international affairs. Osiris. 2006; 21: 1-21; Miller, Clark A. "An effective instrument of peace»: scientific cooperation as an instrument of US foreign policy, 1938-1950. Osiris. 2006; 21: 133-160.

6. Dean, Warren. Brazil and the Struggle for rubber: a study in environmental history. Cambridge and New York: Cambridge University Press; 1987; Soluri, John. Accounting for taste. Export bananas, mass markets, and Panama Disease. Environmental History. 2002; 7 (3): 386-410. 
with Latin America have no precedent. Indeed, overall from 1942 and under the umbrella of Inter-Americanism and hemispheric security, the United States began to participate in its neighbors' domestic affairs in a way «never seen or imagined before» ${ }^{7}$.

Only two further preliminary explanations are needed, related to local contexts. In this paper I deal not only with the United States but with Latin America, a complex undertaking. Latin American countries are very different from one another and each has its own unique history - features important to recognize and keep in mind. However, my aim is not to detail the complexity of local contexts, but to show that even in the light of those differences, continuities exist that come together to form the «big picture».

The second explanation has to do with the lack of Latin American archival sources quoted here. This could lead to the conclusion that national receptions and responses to US intervention in Latin American natural resources were weak or even nonexistent. Of course, this was not the case, and archival sources should be explored in the future. This article should be seen as a first approach to a topic that illustrates what was done from the metropolis. Future investigations should shed light on local and national reactions in the face of imperial attitudes ${ }^{8}$.

\section{Cinchona and its alkaloids}

«Quinas» is the common Spanish name for the plants of the genus Cincho$n a$, and a few of other genera, such as Remijia and Ladenbergia, that, like Cinchona, have medicinal, including antimalarial, properties. The potential of quinas for preventing and curing malaria comes from the alkaloids in their bark: cinchonine, cinchonidine, quinidine and quinine. Each species has different concentrations of alkaloids, and although quinine is the one preferred for fighting malaria, all can be used for this purpose. The mixture of all four alkaloids is called totaquine.

For four centuries, these plants have been known by hundreds of scientific and common names, creating a maddening confusion for naturalists,

\footnotetext{
7. Munro, Dana G. Post-war problems in our Latin-American relations. The American Political Science Review. 1944; 38 (3): 521-530 (522)

8. There are some works on cooperation in public health during the years mentioned; see $\mathrm{n}$. 1 and n. 2.
} 
traders, physicians and historians. In 1998, a review concluded that in the scientific literature there are 330 specific names for Cinchona, while only 23 are accepted as distinct species ${ }^{9}$. The original distribution of the quinas ranges from central Bolivia to northern Colombia and Venezuela, at altitudes from 600 to over 3,000 meters. Only C. pubescens is found outside of the Andes, in the mountains of Costa Rica and the northern coast of Venezuela.

The migration of Cinchona to new latitudes began in the 1860s, and nowadays the plant is found in all tropical regions. The Dutch succeeded in creating a highly productive species, C. ledgeriana, and from the early twentieth century, South American production stagnated while the Dutch broke records every year for the concentration of alkaloids in the plants they produced. Java (a Dutch colony) was the site of 90 to 95 per cent of the world's production and the Dutch quinine processors also held a monopoly due to their exclusive purchasing contracts with Javanese producers. Different manufacturers raised claims against the Dutch monopoly to little effect: Dutch production dominated the market and producers determined prices and destroyed any bark whose quinine content was less than four per cent. Other countries attempted to change this imbalance by creating substitutes via artificial synthesis and encouraging the establishment of plantations, especially from the 1920s. But it was the Second World War that led to renewed efforts in this respect.

\section{The War and the need for raw materials}

As Japan extended its conquests in Asia, the United States inventoried its reserves of strategic raw materials. If in 1938 there were those who suggested that the country look south for new supplies, by 1941 politicians, businessmen and scientists recognized this as an inevitable strategy. Cinchona bark, for example, was imported almost exclusively from Dutch colonies in Southeast Asia, but Latin America had a reservoir of this and other strategic minerals and plants.

As Cinchona bark was a high priority product (along with antimony, chromium, manganese, nickel, quartz, tin, manila fiber, rubber and silk),

9. Andersson, Lennart. A revision of the genus Cinchona (Rubiaceae-Cinchoneae). New York: Memoirs of the New York Botanical Garden, 1998. 
the United States government worked to ensure its reserves and prevent the enemy from doing likewise ${ }^{10}$. The political objective was evident in a letter from Franklin D. Roosevelt to a National Defense Council advisory committee:

«Because markets for forty percent of the normal exports of Latin America have been lost due to the war, there is grave danger that in some of these countries economic and political deterioration may proceed to a point where defense of the western hemisphere would be rendered much more difficult and costly $[. .$.$] One thing we can do is to give sympathetic consideration to$ Latin American products in the procurement of strategic and critical material for the defense program [...] When buying in foreign markets for defense needs, it is my earnest desire that priority of consideration be given to Latin American products and I so request» ${ }^{11}$.

After Pearl Harbor, the United States called an urgent meeting in Rio de Janeiro, where the bases for hemispheric cooperation were laid. In the future, movies, fashion, magazines, music, etc., were to be exclusively from the U. S., and measures would be taken to discourage imports from other countries ${ }^{12}$. Production was monopolized, and the extraction and agricultural production of complementary products, such as Cinchona, were promoted. Actions were taken to make sure that countries like Peru, Nicaragua and Haiti reduced the area devoted to non-complementary products, such as cotton. For example, Peru would be guaranteed the sale of its entire cotton crop if it was less than 155 thousand hectares. Additionally, the country would receive a reward for every one per cent reduction in land under cotton production ${ }^{13}$.

To negotiate conditions with the complex mosaic of Latin American nations, the United States had something that all wanted: money for granting loans and purchase of their products. So the northern nation began to give

10. Beals, Carleton. The coming struggle for Latin America. New York: Halcyon House; 1940.

11. Roosevelt, Franklin D. Letter to Chester C. Davis. Washington DC, Sep 27, 1940. National Agricultural Library. USDA History Collection. Box 1.2/25, Section VII, Series I, subseries 2, Documentary Files, 1907-1982 (bulk 1939-1949).

12. Scotten. Airgram to The Secretary of State, American Embassy. Aug 23, 1944. National Archives at College Park. Box 15; Records of the United States Commercial Company Field Preclusive Operations File 1942-45, Entry 207; RG 234.

13. Mensaje del Presidente del Perú, Doctor Manuel Prado y Ugarteche, al Congreso Nacional, el 28 de jul de 1942 [Quoted on June 30, 2007]. Available at: http://www.congreso.gob.pe/ museo/mensajes/Mensaje-1942.pdf 
credit, with major restrictions, aimed at obtaining certain raw materials. Latin American countries accepted the loans and the non-refundable aid, and created institutions to receive the money, directed by US staff, while also creating the laws necessary to permit access to products. The US government also put large-scale institutional machinery into motion: some institutions and companies were created $a d$ hoc, while others were changed to suit the economic war. There were institutions for controlling credits, for creating agricultural development stations and promoting complementary products, for the development and purchase of products, for trade controls, for public health intervention, for propaganda and rehabilitation, for the lend-lease of war materials, etc. In Latin America, all of these institutions were coordinated by the Interdepartmental Committee on Scientific and Cultural Cooperation, created a few years before, in 1938.

The operation involving Cinchona bark and its alkaloids went to a special agency, the Defense Supplies Corporation (DSC), but some aspects were delegated to corporations, experimental stations (managed by the USDA) and other research and education institutions. Universities, laboratories, industries, private companies and pharmaceutical companies participated directly or indirectly. The aim was to monopolize the market through strategies such as blockades and black lists. A key strategy was the use of exclusive purchasing agreements, with loans and some technology transfer in the form of technical assistance and genetic material, but not in the latest technologies. According to the assistant director of the Office of Foreign Agricultural Relations (OFAR), Latin America

«must continue on to a new era. An era when hundreds of merchant ships will carry rubber, drugs, fibers, oils and herbs from south to north — and take back increased amounts of automobiles, tractors, plows, sewing machines, shirts, shoes. Many other things will be traded, in that era when the new products of the Americas will more nearly complement each other» ${ }^{14}$.

But loans were not a guarantee: it was crucial to control how the money would be invested. Latin American governments were good partners, with an enormous agricultural frontier and the desire to collaborate; and in technical

14. Agriculture in the Americas, Interview with Dr. Earl N. Bressman, Office of Foreign Agricultural Relations, Sep 11, 1941, Transcribed. National Archives at College Park. Box 1479; Records of the Division of Agriculture General Correspondence (E-136); RG 229. 
terms, they were as reliable as an old-fashioned US peasant. So along with the money came agronomists, botanists, economists, chemists, experts in soil conservation and foresters. US science was aimed at transforming the entire landscape and the management of more than 100 products.

Never before had United States government agencies and companies enjoyed so many privileges and concessions as they did during the war. In several countries, such as Haiti, Bolivia and Ecuador, specific institutions were created to channel the loans. The way institutions would function was determined by laws written in Washington. In 1942, after a successful effort in Haiti, Ecuador established the Ecuadorian Development Corporation (EDC) with a loan from the Eximbank. The same occurred in Bolivia with the Bolivian Development Corporation. The report on the corporation and the development plans for Ecuador had two parts: in the first were the emergency programs that the United States considered of utmost urgency. This part of the report - the Foreword- was not shared with Ecuador. In fact, instructions to that effect, included in the forward, read as follows: «The foreword should be excluded from the report submitted to the Ecuadorian Government» ${ }^{15}$.

The fate of the EDC was planned in Washington D.C. by representatives of Eximbank, the Board of Economic Warfare, the State Department, the OFAR, the Office of the Coordinator of Inter-American Affairs and the Soil Conservation Service. Ernest G. Holt, leader of the economic mission to Ecuador, said that the government of that Andean nation was open to making all necessary legal changes, including those permitting the creation of monopolies. Participants at that meeting agreed that «the Ecuadorian officials would agree to anything in principle, but that the types of arrangements foreseen would not be carried out over a period of years» ${ }^{16}$. In other words, the short term nature of the program was clear from the beginning to the planners in Washington.

Holt's plan for Ecuador, like Melvin Bohan's plan for Bolivia, was to build roads, draw labor from the mountains to the frontier to be opened

15. Ecuadorian Economic Resources Mission. Preliminary production plan and cost estimate for large scale rubber and abaca production in Ecuador under a national corporation. Ecuadorian Economic Resources Mission; 1942.

16. Minutes of Meeting held in Mr. Wheeler's Office, Mar 31, 1942. National Archives at College Park. Box 10; Records of the United States Commercial Company, General Country File 1942-48, Entry 200; RG 234. 
and develop sources for the species to be planted. One aide criticized the establishment of large plantations of Cinchona, rubber and other products if the project was ultimately to be executed by small farmers, but his opinion went no further than the minutes. The governments were to provide land and export privileges. Technical and administrative posts would be dominated by US personnel, so the Eximbank could control the corporations.

Both from the viewpoint of its contemporaries and in retrospect, the EDC was a corrupt institution concerned only with the short term ${ }^{17}$. Although the work was mainly done on the coast, an expensive office was set up in Quito and then-President Carlos Arroyo del Río was the first to ask for a job for his son, a request subsequently made by other influential ministers of the time. Staff operated at lightning speeds, dedicating themselves exclusively to the production of war materials and neglecting those that would have been of permanent interest. The money was spent quickly and the debt increased: the original loan for the EDC amounted to $\$ 5$ million; by July 1944 it had increased to over $\$ 35$ million $^{18}$.

\section{The quest for Cinchona in the Andes}

What is especially unique about Cinchona production promoted during World War II, as compared to previous exploratory efforts, is the huge number of scientists involved; the Cinchona Program required not only agronomists for agricultural testing and improving, but also the immediate participation of botanists, foresters and chemists.

By the time the United States returned to the Andean forests and to the old Cinchona plantations of the American continent, the only country that had experienced a resurgence of the bark industry was Bolivia, which shortly before had opened a large national quinine factory. In addition, in Guatemala, the pharmaceutical company Merck \& Co. had been experi-

17. Ecuador, Ministerio de Economía. El Ministerio de Economía y la Corporación Ecuatoriana de Fomento. Presentación de documentos comprobatorios de las gestiones del Ministerio en defensa de los intereses nacionales. Quito: Ministerio de Economía, Talleres Gráficos Nacionales; 1945.

18. Gobierno del Ecuador. Ratifícanse los convenios suscritos en Washington. Decreto n. 1639 del 4 de noviembre de 1943, Registro Oficial n. ${ }^{9}$ 953, p. 6174-6175. 
menting with the plant for close to a decade and encouraged by the US government, as a strategy to get rid of the Dutch monopoly.

The plan for Latin America was divided into three main parts:

1) to develop all sites with commercial quinas and control their price to prevent speculation and maintain a stable situation in the long term;

2) to develop plantations that could compete with the Kina Bureau (the Dutch monopoly) or any other group and ensure provisions in case of any emergency;

3) to train people in producing countries to, at the end of the missions, take over the industry with the nominal help of the United States.

Part of the plan was to promote the use of quinine, atebrine and any other substitutes in the hemisphere ${ }^{19}$.

As the goal was to stockpile all of the bark and its alkaloids, one of the first steps was to find US importers with knowledge of the Andean market. These companies began to purchase bark in the name of the DSC from June 1942, but to the US agency it seemed to be «an emergency within the emergency program», because the private companies lacked the authority to negotiate privileges. It was therefore necessary to sign agreements with each republic to develop the exploitation of the product in a major program, preventing the bark from getting into the hands of the Axis, and also encouraging local producers to engage with the market (they did not wanted to invest in something that had caused losses during the First World War due to the lack of scientific exploration, chemical analysis and control over prices, production and trade $)^{20}$. So agreements were gradually signed with the DSC assuming the duty and right to buy all of the bark provide technical assistance for the exploration of forests and establish plantations and factories. At the same time, agreements were made to establish agricultural experimental stations managed by USDA personnel, or to reinforce others

19. Report on Cinchona Program, Oct 22, 1942. National Archives at College Park; Box 10; Records of the United States Commercial Company relating to USCC Activities in Latin America 194245; Entry 212; RG 234.

20. Gardiner, Arthur E. (Director, Foreign Procurement Development Branch). Letter to James H. Head, Chairman, Special Committee Investigating the National Defense Program, Aug 29, 1945. National Archives at College Park. Box 5; Records of the United States Commercial Company Administrative Subject File 1942-48, Entry 199; RG 234. 
already existent. Those stations would be used for performing experiments with Cinchona.

As much of Cinchona extraction/production depended on work in the forests, young US personnel with some experience in exploration (but not necessarily in the tropics) were selected. Everything was planned for their work, including compensation for injuries while fulfilling their duty in «insane» climates with unusual means of transport ${ }^{21}$. In October 1942 the first botanists arrived in Colombia: Francis Raymond Fosberg of the National Arboretum, and William Campbell Steere of the University of Michigan. They were the first of more than 20 botanists to be officially involved in the Cinchona Program. Colombia was the first of the six republics that signed an agreement with the DSC in relation to the production of Cinchona, in September 1942. The next were Peru, Guatemala, Costa Rica, Ecuador and Bolivia.

The role of the botanists was to find, identify and collect quinas and related plants that could be valuable for extraction or cultivation programs. Meanwhile, the foresters were to calculate the volume and propose the method for getting it to seaports. It was necessary to make an inventory of the existent species and varieties, as past knowledge had been a «trade secret», and a long time had passed since the end of the last Cinchona boom in Colombia.

Finding quinas was not difficult because they grow at defined altitude ranges and usually in patches of five to fifty individuals ${ }^{22}$. The difficulty was finding the species with many alkaloids and then removing, drying and transporting the bark. Identification was a challenge because of the diversity of species and varieties, and the resultant diversity in alkaloid concentration. Some approaches were tried to solve this problem. For example, they used the Grahe test to find out whether the trees had alkaloids or not, but although this gave a «yes or no», it did not revealed «how much». To deal with this, a portable machine for checking quality in the field was invented in 1943. It was an ingenious system that could be used by untrained people,

21. Health precautions of Central and South America and the Caribbean Area, Prepared by the Medical Intelligence Branch, Preventive Medicine Division, S.G.O., US Army, Oct 10, 1941, and revised Jan 29, 1943. New York Botanical Garden Archives. Box 7; Series 8; William C. Steere Papers, 1927-1958.

22. Steere, William Campbell. The Cinchona-bark industry of South America. The Scientific Monthly 1945; 61 (2): 114-126 (124). 
and the first four units were sent to be tested, but little more is known about them, probably because they enjoyed little success: although the machines could solve the "how much» problem, they could not tell «which alkaloids». In the end, the best method continued to be the collection of samples and their analysis in a few permanent laboratories.

A rediscovery of major impact was that of C. pitayensis in the Colombian Andes. This was relevant because in Colombia the pitayensis has more alkaloids than any other commercial species. As the range of this species continued to expand, it was presumed that this could also occur in Ecuador, so Steere went to that country in July 1943. He found pitayensis in Ecuador and was surprised that it was unknown. According to the scientist, this was because traditional knowledge claimed that the best Cinchona grows below 1,700 meters above sea level ${ }^{23}$. After the initial skepticism, he convinced the local people that this bark was good and they agreed to seek out other locations. By mid-1943 Ecuador was the second largest producer in Latin America, thanks to the «scientists in business» group which, according to Froelich Rainey, director of the mission in Ecuador, was what they had become ${ }^{24}$.

But productivity did not mean quality, because the best bark went onto the black market and was smuggled. The Ecuadorian government lacked the technicians and the organization to control the industry and turned to the United States for assistance. Rainey eventually learned that an Italian company that processed Cinchona bark in Quito was sending it to the German and Italian armies in North Africa. With the government's permission, a team was sent to a farm to be met by a colonel who was well-paid to organize a team that went to the páramo (highlands) where, at an altitude of 4,000 meters, they intercepted a pack of 14 mules. After that episode and an agreement with the factories, the problem was solved and large quantities of bark flowed to Guayaquil.

Successful exploration depended heavily on logistical support, local guides and informants. It was considered good to have native guides but

23. Steere, William Campbell. The botanical work of the Cinchona Missions in South America. Science. 1945; 101 (2616): 177-178 (177).

24. Rainey, Froelich. Quinine hunters in Ecuador. National Geographic Magazine. 1946; 89 (3): 341 363. 
not to rely entirely on their word ${ }^{25}$. In theory, the local people would be trained to assist the scientists, but they ended up having to teach them how to move, where to go, and how to recognize plants. Botanist Wendell $\mathrm{H}$. Camp was one of the explorers who most appreciated the help of his assistants. His three assistants were excellent models: Francisco Prieto, Manuel Giler and Henning Jorgensen. Prieto was one of a long line of Indian cascarilleros and

«took pains to teach me the lore of bark fiber hunting, as well as the multitudinous ways in which the bark was faked or diluted. He was a conscientious and excellent workman and completely to be trusted to operate alone. As a result he was often sent on special trips when it was not expedient to make up a full-scale expedition» ${ }^{26}$.

Tropical nature was also a problem for all of them. Camp, for example, only loved nature when it was not «warm, rainy, muddy» ${ }^{27}$.

Laboratories were also important. In the past, the quina business made and destroyed fortunes: the former when a forest with highly productive varieties was discovered, and the latter when a businessman was duped with adulterated or poor quality bark. The Dutch had homogenized the quality of quinas in Java, but with the return to the South American forests the topic became significant again. Success depended in large part on the ability to obtain quick and reliable analyses, so the DSC set up laboratories in Quito, Lima, Bogota and La Paz. The samples could arrive there as botanical collections from the scientists, or could be taken from merchandise already harvested by individual peasants, communities or landowners. If it came from an untouched quina area, then the harvesting process began; if it was part of a stock already harvested, the price to pay could be determined.

Without such analyses many headaches would have been suffered when the bark reached the factories, but they also served to make discoveries, such as the fact that at certain times of the year Cinchona could have more alkaloids, that alkaloids varied from one individual to another, that

25. Fosberg, F. Raymond. Manual de quinas colombianas, second edition. Bogotá: Foreign Economic Administration; 1944.

26. Camp, Wendell H. Plant hunting in Ecuador. Memoirs of the New York Botanical Garden. 1952; 8 (1): 1-24 (2).

27. Daily Notes of Wendell Camp, Cuenca. New York Botanical Garden Archives. Box 1; Series 3, Field Trips and Expeditions; Wendell Holmes (Red) Camp Papers. 
there were size-alkaloid ratios and that the branches have fewer alkaloids than the trunk. However, the laboratory tests were not always reliable ${ }^{28}$ : the biggest fiasco happened in Colombia, where for a long period the test results gave negative errors ranging from six to eight per cent, resulting in serious losses for local producers.

\section{Extraction and sale of Cinchona}

After exploration came extraction, purchase, transport and export of the bark. This was done by foresters and businessmen who had to learn everything about the complex Cinchona extraction process and markets ${ }^{29}$.

Extraction required the specialized labor of the cascarilleros, Indians who entered the forests to harvest the bark. To find quinas they had to walk through the forest or recognize the trees from an adjacent hill. They identified the quinas by sight, on the basis of the characteristics of a tree's trunk and leaves.

After identification, the trees were cut down, so they would grow again (those that were only peeled and left standing died) ${ }^{30}$. Then they spent an hour removing the bark using machetes and knives. But the real challenge came later: carrying 70- to 100-pound loads over steep terrain to the dryer.

The bark was dried because when wet it was harder to transport and took up too much space in warehouses and on ships. When dried it lost between 70 and 75 per cent of its weight (if crushed the cost would have been reduced one hundred fold, but this idea was discarded because it increased the chances of adulteration $)^{31}$.

Traditionally, the drying occurred outdoors and although the cascarilleros and dealers knew that the sun damaged the bark, the technicians

28. Rainey, Froelich. Message to Paul H. Nitze, Mar 21, 1944. National Archives at College Park. Box 14; Foreign Agricultural Service Reports from Agricultural Attaches relating to international agriculture conferences and congress 1931-1950, Entry 4A; RG 166.

29. Margolis, Charles (Chief, Colombian Cinchona Division). Letter toWilliam C. Steere, Bogotá, Mar 13, 1943, Board of Economic Warfare, American Embassy, Bogotá. New York Botanical Garden Archives. Box 7; Series 8; William C. Steere Papers, 1927-1958.

30. Steere, n. 22, p. 125.

31. Conversation between Snyder (S.B. Penick \& Co.) and Gregory (BEW) on Cinchona grinding, Nov 14, 1942. Daily Negotiations Report, W. L. Gregory, Board of Economic Warfare. National Archives at College Park. Box 5; Records of the United States Commercial Company Administrative Subject File 1942-48, Entry 199; RG 234. 
noticed that the greatest loss of alkaloids was due to fermentation. So they built precarious dryers in the middle of the forest, in small clearings with a fire burning to speed up the drying process. Where there were large-scale operations, ovens that could hold several tons were built.

The conditions around the extraction and drying points were appalling. As Froelich Rainey testified, at around 1,500 meters above sea level, in the midst of smoke from the dryers, he saw Indians with malaria and other diseases that «could only be cured through exposure to the sun» ${ }^{32}$. Though this is an impression based on empirical, rather than scientific, knowledge, it describes very well the working conditions in the forests where Cinchona was obtained.

Transport involved more than just removing the bark from the forests. After being transported to a collection point by porters, mules and donkeys, the dried bark was taken by truck or train to the ports of Callao, Guayaquil, Buenaventura and Barranquilla. It took about four months from the moment of purchase for the bark to reach the United States ${ }^{33}$. The hardest part was reaching the main roads, a situation complicated by the labor problem: in places like Ecuador, the towns were a long way from the forests and were not popular destinations for workers. Bolivia had similar problems with all of its programs, and Guatemala lost workers during the coffee season. Hence, the colonization schemes undertaken by all governments.

Much of the work was done by local agents who were responsible for organizing and supervising the harvest, drying, transport, storage and shipment. They were usually local businessmen with experience in dealing with plant products, who worked with scientists and farmers. The process was coordinated by a central agent, which was no guarantee. In Colombia, Charles Margolis, head of the mission from January 1943, had one-and-a-half million dollars to purchase Cinchona bark and quinine. Margolis was not a trustworthy character: he was found guilty of corruption and sentenced to a year and a day in prison for accepting a bribe.

Eventually, between December 1941 and August 1945, the United States imported about 30 million pounds of dried bark from Latin America,

32. Rainey, Froelich. Quinine hunters in Ecuador. National Geographic Magazine. 1946; 89 (3): 341 363 (356).

33. Sanger, Quintin M. Procurement and development of strategic and critical raw materials. National Archives at College Park. Several boxes in: Records of the Administrative Records of the Analysis Division, Historical Monographs Prepared by the Division, Entry 145; RG 169. 
to which must be added approximately 700 thousand ounces of processed alkaloids obtained using technologies already present before the War in the countries from which the product came. The United States never transferred technology to process alkaloids; it preferred to buy the bark, avoiding problems with product quality and possible future competition. Colombia was the largest supplier of bark, followed by Ecuador, Bolivia and Peru. In the following years the bark continued to be imported, reaching a total of over 40 million pounds between 1941 and 1947.

\section{Nurseries, plantations and alkaloids factories}

Planting programs were almost mandatory, otherwise Latin American countries would have been unlikely to accept the whole program, which also included the upgrading or installation of factories to process the alkaloids ${ }^{34}$.

Old plantations in Peru, Ecuador and Guatemala were surveyed and new ones were promoted from Mexico to Bolivia. Though US personnel knew that the plantations would not be profitable in the long term, they argued that quina supplies could be depleted in the Andes, or that the Japanese could destroy the Javanese plantations. The plants required ten to twelve years to grow, but poor quality alkaloids could be obtained in only three years, so plantations spread across the continent. Countries such as Mexico, Brazil, Nicaragua, Venezuela, Haiti and Puerto Rico started to produce Cinchona ${ }^{35}$.

The genetic material for plantations came from different sources: seeds taken from the Philippines and grown in Maryland, the Guatemalan material of Merck \& Co., and the C. calisaya plantations of Bolivia and Peru. The aim of the intense seed traffic was to find the most productive variety and to standardize it.

The largest plantation projects were implemented in Guatemala and Costa Rica. At the first site, from 1934, Merck \& Co. initiated a project with

34. Report on Cinchona Program, Oct 22, 1942. National Archives at College Park. Box 10; Records of the United States Commercial Company relating to USCC Activities in Latin America 194245; Entry 212; RG 234.

35. Banda C., Francisco. Quinine and substitutes. May 26, 1943. National Archives at College Park. Box 33; Records of the Defense Supplies Corporation Commodity Procurement File 1942-49, Entry 159; RG 234. 
C. ledgeriana seeds, but these efforts were modest until 1939, when the advent of the War motivated the foundation of Experimental Plantations Inc., a subsidiary of the pharmaceutical company that bought the El Naranjo farm. There was a nursery of Cinchona with 60 thousand square yards of beds where close to 15 million plants were grown, mostly C. pubescens and hybrids (the aim was to reach 48 million plants). In 1943 the first large-scale commercial plantation was located at El Naranjo: over 500 thousand acres.

While El Naranjo was a large private provider in Guatemala, in 1943 the Foreign Economic Administration took over a program that aimed to provide 300 million plants to producers. The site chosen was El Porvenir farm and its surroundings: there the FEA installed one of the best laboratories for the analysis of alkaloids, and the site became the largest nursery on the continent, ahead of El Naranjo. It employed about 2,000 people. The project was abandoned in late 1944 because the forests of South America were providing enough bark, and in 1949 the bilateral agreement ended. The Guatemalan government bought the property under the condition that the United States would have access to genetic material and that Guatemala would not give access to other countries ${ }^{36}$.

The same thing happened in Costa Rica. With the support of Merck \& Co. and the US government, the Experimental Plantations project started in 1942 with the purchase of farms ${ }^{37}$. The results were not as good as in Guatemala, but by the end of the next year there were over half a million plants. In addition to private farms, the DSC signed a contract with the government of Costa Rica to lease 1,250 acres of the Isla Bonita farm to plant C. ledgeriana. Its official name was the American Quinine Plantation.

With regard to the processing of alkaloids, some of the bark was directed to local factories running on old technology, because the United States was not interested in encouraging the industry in the Andes: «Our purchase [of alkaloids] desirable only to clean up market and not to en-

36. Wells, Milton K. (first Secretary of Embassy). Letter to The Secretary of State, on transmitting exchange of notes with Guatemalan Ministry of Foreign Affairs with regard to certain assurances on the part of Guatemala concerning the future exploitation of Cinchona on the El Porvenir Plantation, Guatemala, Mar 16, 1949. National Archives at College Park. Box 13; Foreign Agricultural Service Reports from Agricultural Attaches relating to international agriculture conferences and congresses 1931-1950, Entry 4A; RG 166.

37. Rosengarten, Frederic. History of the Cinchona Project of Merck \& co., inc. and Experimental Plantations, inc., 1934-1943. Rahway, N. J.: Merck \& Co., inc.; 1944. 
courage production» ${ }^{38}$. The agreements with Peru and Ecuador included a clause requiring the United States to finance a factory in each country, but this was finally abandoned in favor of plantations. At the meetings of the WPB and BEW, it was concluded that the establishment of factories in Latin America was equal to promoting competition with US factories, and the decision not to provide any technology prevailed despite the agreement to do so. At a meeting it was agreed that: «WPB is definitely committed to a policy of preventing us from assisting Latin American countries in setting up extraction plants» ${ }^{39}$.

\section{The end of the Cinchona Program}

The end of the war brought consequences for raw material extraction and agricultural cooperation programs. In the case of Cinchona, its termination converged with the recovery of plantations in Southeast Asia, the development of synthetics, and the fact that by June 1944 the United States had enough antimalarial products to last until $1947^{40}$. In Ecuador, botanical director Steere was not sorry: in July 1944 he was highly disillusioned and had amoebic dysentery and malaria. By April 1945 the last botanist in Ecuador was Camp, who remained there much to his regret ${ }^{41}$. In Colombia, around January 1945, with the invasion of the Philippines and the end of the war in the Pacific, the office was ordered to close ${ }^{42}$.

38. Crowley, Adler and Cone. Letter to Rainey, Mar 30, 1944. National Archives at College Park. Box 104; Records of the Bureau of Areas of the Pan American Branch, Pan American Records Stat. item 384; RG 169.

39. Conversation between representatives of the WPB and the BEW, Keith G. Cone, Daily Negotiations Report, Board of Economic Warfare, Feb 22, 1943. National Archives at College Park. Box 5; Records of the United States Commercial Company Administrative Subject File 1942-48, Entry 199; RG 234.

40. Taylor, Walter H. Memorandum to Howard J. Trueblood, on Background material on Cinchona production in Latin America, collected from Sources Available to the North and West Coast Division, Feb 10, 1945. National Archives at College Park. Box 14; Foreign Agricultural Service Reports from Agricultural Attaches relating to international agriculture conferences and congresses 1931-1950, Entry 4A; RG 166.

41. Camp, Wendell. Letters to William Steere: La Cuenca (otherwise known as The Hole), Feb 24 1945, and Quito, Ap 14 1945. New York Botanical Garden Archives. Box 5; Series 8; William C. Steere Papers, 1927-1958.

42. General Progress Report, Colombia Cinchona Division, Oct 24 1945. National Archives at College Park. Box 981; Records of the Administrative Records of the Analysis Division, Entry 165; RG 169. 
By 1945 purchases continued (without new exploration), but on August 12 an urgent telegram arrived in Quito ordering the termination of the program by November 30. Anything that could not be shipped before that date would not be bought ${ }^{43}$. As for quinidine, which by that time had become the priority alkaloid, the order was to obtain as much bark with quinidine as possible.

The agreements ended in November, accounts were closed, debts were paid, and the Cinchona Program balance sheets end on that date. There was a strategy to get rid of some bark instead of sending it to the US processing factories; it is known that 23,040 pounds of bark were destroyed in August ${ }^{44}$. Although the amount is large, it would not be the first time that the medicine was reduced to ashes: for years the Kina Bureau had bought and destroyed South American bark just to remove it from the market. At the end, through the Cinchona Program the United States imported about 40 million pounds of dry bark, a figure that does not include antimalarials processed in Latin American factories.

In 1948, with the synthetic atebrine and chloroquine reigning as antimalarial products, the South American bark was still processed in the United States. The pharmaceutical companies advised that the controls should be relaxed only when the Kina Bureau no longer represented a monopoly threat; this is why, when leaving the plantations of Guatemala and Costa Rica, contracts signed with the US government prohibited these countries from cooperating with foreign powers. The quinine industry, so highly promoted before, showed its true unsustainable face with the exit of the US agencies. But even when protectionism had ended in the Andean countries, some people continued promoting the cultivation and processing of the plant.

43. Carr, Alfred B;; McDermott, Peter A. Telegram to Embassy, Quito, Aug 9, 1945. National Archives at College Park. Box 104; Records of the Bureau of Areas of the Pan American Branch, Pan American Records Stat. item 384; RG 169.

44. Bogren, A. M. (Cinchona Representative). Memorandum to P. A. McDermott, Chief, General Commodities Division, Bureau of Supplies, Foreign Economic Administration, Sep 13, 1945. National Archives at College Park. Box 11; Records of the United States Commercial Company General Country File 1942-48 1942-48, Entry 200; RG 234. 


\section{Epilogue}

One aspect that stands out regarding the Cinchona program is the immediate purpose of US intervention in Latin America during the Second World War, namely, to stimulate the production of strategic raw materials hitherto concentrated in Southeast Asia. Although since 1939 it was known that the plantations and production programs would be temporary ${ }^{45}$, a double discourse was disseminated while a model of dependence on agricultural production and raw material exportation in exchange for loans and technology was consolidated.

The United States sought to coordinate inter-American trade in order to defend and unify the economies of the American nations. The idea was to use surplus, absorb stocks, grant loans, expand strategic and complementary products for the war, offer preferential rates, etc. That boom led to a change from Latin American dependence on European technology to a dependence on technology, money and cultural products from the United States. Once immersed in the dynamic, Latin American countries would have to borrow money to stimulate the discovery of new products, clear the forests and purchase machinery and agricultural inputs. When the emergency programs ended, only a few acknowledged in public that they might have introduced unnecessary crops.

Scientists, with the support of businessmen, attorneys, diplomats, etc., promoted the extraction of forest products and the expansion of the agricultural frontier on a scale never seen before, mobilizing workers to areas with problems related to transportation, food and disease. Scientists planned this occupation of the newly opened areas and identified the crops to be produced; in doing so, they created new forms of relationship with nature. In the end, they were successful in directing the efforts of the Latin American republics towards complementary products that the United States was unable to produce at home.

This intervention went beyond the forest extraction and agricultural fields. The policy of selling partial technology, or of conditioning loans to the purchase of United States technology, became common practices despite sporadic resistance displayed by Latin American nations ${ }^{46}$.

\footnotetext{
45. Newcomb, Robinson. The United States and Southeast Asia's strategic products. Far Eastern Survey. 1939; 8 (8): 87-94.

46. Galeano, Eduardo. Las venas abiertas de América Latina. Madrid: Siglo XXl; 2003 (1971), p. 316.
} 
In the nineteenth century, technology enabled the British to conquer Africa and Asia, with steam boats, quinine and weapons ${ }^{47}$, and in the twentieth century, the United States did the same with roads, machinery, seeds and a loan system with the promise of purchase. Science also provided, as in the nineteenth century, an intellectual justification for imperialism: in this case it was that of inferior technology, a «primitive agriculture» that needed «assistance» and «cooperation». With republics open to any recommendation, imperialism regarding raw materials was easily implanted. As has been noted above, science was «an effective instrument of peace» ${ }^{48}$, and the Cinchona Program illustrates very well how the «North-Americanization» of scientific endeavors in Latin America occurred in all fields, from botany to soil science and medicine.

Of course, this is not to say that the United States had the same agency that the Spanish in Latin America, the French in the Ivory Coast, the Germans in Tanganyika, the Dutch in Java, or the British in Ceylon. But it is equally impossible to claim that the playing field was a level one, that relations were established between equals in terms of power. Undoubtedly, the United States could not simply impose agricultural or extraction policies in Latin American countries, but in the end, in most cases, that was what happened. US agencies planned the agricultural development of these nations, the frontier to be opened, and the products to be developed. In the case of Cinchona, Bolivia was the only nation that did not accept US rules, but in the end it had to agree to sell its Cinchona to the United States. If it is true that, historically, US imperialism is much clearer in the Caribbean basin than in the Andean countries, it is also true that relations during World War II with those nations are based on a large dose of implicit or explicit imperial threats.

Intervention served to test trade strategies from a State perspective, for example, by extending credit and determining how the loans would be used. As in the African context, in Latin America «development» was tested in the social, agricultural, environmental and other spheres.

As for local scientists and science, technocrats created institutions to advise the government on new production, and other institutions arose, such as agricultural experiment stations (some directly controlled by the

\footnotetext{
47. Headrick, Daniel R. The tools of empire: technology and European imperialism in the nineteenth century. New York and Oxford: Oxford University Press; 1981.

48. Miller, n. 5.
} 
United States) and research and education sites, such as the Instituto Interamericano de Cooperación Agrícola (IICA) in Costa Rica. They were excellent platforms for taking the tropics by storm. Latin American scientists welcomed, disseminated and consolidated the model of US economic botany, and sustained the idea of opening the agricultural frontier and producing crops for export.

As for the visiting scientists, who emulated the naturalists who had traveled across America centuries before, their travels provided excellent training as many were unfamiliar with tropical plants $i n s i t u^{49}$. On a more technical level, alkaloid extraction led to technological innovations, and it was the pressure to obtain synthetic drugs which led to extensive biomedical studies ${ }^{50}$. Furthermore, the identification of Cinchona and other Rubiaceae presented challenges that were overcome through new chemical and histological analyses. Wendell H. Camp used this data to open a research field in a 1949 article in which he proposed a taxonomy based on biochemical characteristics. In a letter to Standley, he concluded: «I fear that if the analysis of field samples is soon to be correlated with botanical specimens your days of peace and comfort will be over ${ }^{51}$. What he meant was that taxonomy based solely on morphological characteristics would have to change to include molecular analysis. Science in the field, coupled with laboratory work, was the key to the development of life sciences in the twentieth century, and also to that of the imperial enterprise.

The war missions strengthened the role of US scientists and agencies in the imaginations of Latin American nations: they became experts charged with determining paths of research and the path of development that all would embrace a few years later with Truman's call for development. They also consolidated the belief in the ability of United States technology to solve their production problems. That technology would be introduced at the expense of local initiatives.

US technical assistance spread around the globe, and scientists began to occupy diplomatic positions and scientific cooperation became more

49. Wiggins, Ira. Letter to William Steere, Oct 20, 1945. New York Botanical Garden Archives. Box 8; Series 8; William C. Steere Papers, 1927-1958.

50. Wiselogle, Frederick Y. A survey on antimalarial drugs 1941-1945, 2 vols. Michigan: J. W. Edwards; 1946; Slater, Leo B. War and disease: biomedical research on malaria in the twentieth century. Piscataway NJ: Rutgers University Press; 2009.

51. Camp, Wendell Holmes. Letter to Paul C. Standley, Cuenca, Aug 26, 1944, New York Botanical Garden Archives. Steere Papers, Box 7. 
than simply a cultural interchange: in the post-war years, it was also related to technological development, economic growth and national security ${ }^{52}$. That is how botany, forestry and other sciences once again came to serve the imperial project.

\section{Acknowledgments}

I originally used the information in this paper for my $\mathrm{PhD}$ dissertation. The research was possible thanks to a MAEC-AECI grant from the Ministerio de Asuntos Exteriores y Cooperación of Spain. For my travel to the US archives, I received support from the Centre d'Història de la Ciència, Universitat Autònoma de Barcelona; the Chemical Heritage Foundation; and the American Institute of Physics. 